\title{
Thyroid hormones and breast cancer association according to menopausal status and body mass index
}

Carolina Ortega-Olvera' ${ }^{1}$, Alfredo Ulloa-Aguirre², Angélica Ángeles-Llerenas ${ }^{3}$,

Fernando Enrique Mainero-Ratchelous ${ }^{4}$, Claudia Elena González-Acevedo ${ }^{1}$, Ma. de Lourdes Hernández-Blanco ${ }^{1}$, Elad Ziv ${ }^{5,6}$, Larissa Avilés-Santa ${ }^{7}$, Edelmiro Pérez-Rodríguez ${ }^{8}$ and Gabriela Torres-Mejía ${ }^{3,9^{*}}$ (D)

\begin{abstract}
Background: Thyroxine (T4) has been positively associated with tumor cell proliferation, while the effect of triiodothyronine (T3) on cell proliferation has not been well-established because it differs according to the type of cell line used. In Mexico, it has been reported that $14.5 \%$ of adult women have some type of thyroid dysfunction and abnormalities in thyroid function tests have been observed in a variety of non-thyroidal illnesses, including breast cancer (BC). These abnormalities might change with body mass index (BMI) because thyroid hormones are involved in the regulation of various metabolic pathways and probably by menopausal status because obesity has been negatively associated with BC in premenopausal women and has been positively associated with BC in postmenopausal women.

Methods: To assess the association between serum thyroid hormone concentration (T4 and T3) and BC and the influence of obesity as an effect modifier of this relationship in premenopausal and postmenopausal women, we measured serum thyroid hormone and thyroid antibody levels in 682 patients with incident breast cancer (cases) and 731 controls, who participated in a population-based case-control study performed from 2004 to 2007 in three states of Mexico. We tested the association of total T4 (TT4) and total T3 (TT3) stratifying by menopausal status and body mass index (BMI), and adjusted for other health and demographic risk factors using logistic regressions models.
\end{abstract}

Results: Higher serum total T4 (TT4) concentrations were associated with BC in both premenopausal (odds ratio (OR) per standard deviation $=5.98,95 \% \mathrm{Cl} 3.01-11.90)$ and postmenopausal women $(\mathrm{OR}$ per standard deviation $=2.81,95 \% \mathrm{Cl}$ 2.17-3.65). In premenopausal women, the effect of $\Pi 4$ decreased as BMI increased while the opposite was observed in postmenopausal women. The significance of the effect modification was marginal $(p=0.059)$ in postmenopausal women and was not significant in premenopausal women $(p=0.22)$. Lower $T 3$ concentrations were associated with BC in both premenopausal and postmenopausal women and no effect modification was observed.

Conclusions: There is a strong association between $B C$ and serum concentrations of $T \pi 3$ and $T 4$; this needs to be further investigated to understand why it happens and how important it is to consider these alterations in treatment.

Keywords: Thyroid hormones, Triiodothyronine, Thyroxine, Obesity, Breast cancer

\footnotetext{
* Correspondence: gtorres@insp.mx

${ }^{3}$ Centro de Investigación en Salud Poblacional, Instituto Nacional de Salud

Pública, Av. Universidad No. 655, Col. Santa María Ahuacatitlán, Cuernavaca

C.P. 62100, Morelos, México

${ }^{9}$ Instituto Nacional de Salud Pública, Centro de Investigación en Salud

Poblacional, Avenida Universidad 655, Col. Santa María Ahuacatitlán, C.P.

62100 Cuernavaca, Morelos, México

Full list of author information is available at the end of the article
}

(c) The Author(s). 2018 Open Access This article is distributed under the terms of the Creative Commons Attribution 4.0 International License (http://creativecommons.org/licenses/by/4.0/), which permits unrestricted use, distribution, and reproduction in any medium, provided you give appropriate credit to the original author(s) and the source, provide a link to the Creative Commons license, and indicate if changes were made. The Creative Commons Public Domain Dedication waiver (http://creativecommons.org/publicdomain/zero/1.0/) applies to the data made available in this article, unless otherwise stated. 


\section{Background}

The association between thyroid hormones and the risk of breast cancer (BC) has been reported in epidemiological studies $[1,2]$. A positive association has been reported between thyroxine (T4) and risk of $\mathrm{BC}$, which is more pronounced in overweight and obese women [1]. Negative associations have been reported between triiodothyronine (T3) and BC among premenopausal women; in contrast, positive associations have been observed among postmenopausal women [2]. It has been shown that in in vitro studies, thyroid hormones affect the growth of BC-derived cell lines [3], lung cancer [4], and glioblastoma [5]. T4 has been shown to increase cell proliferation through the $\alpha v \beta 3$ integrin receptor found on the plasma membrane of cells [3]. In contrast, the effect of T3 on cell proliferation has not been well-established because it differs by the type of cell line used [6-8]. These effects are important, since abnormalities in thyroid function tests have been observed in a variety of non-thyroidal illnesses, without preexisting thyroid or hypothalamic-pituitary disease [9]. Furthermore, these abnormalities might change with body mass index (BMI) because thyroid hormones are involved in the regulation of various metabolic pathways (e.g., adaptive thermogenesis and glucose metabolism) that are relevant for resting energy expenditure and changes in body weight $[10,11]$.

Worldwide, obesity has increased to epidemic proportions in recent years. According to the World Health Organization (WHO) in 2014, 40\% of women over age 18 years were obese and $15 \%$ were overweight [12]. By 2016, in Mexico, 37\% of women older than 20 years were overweight, and the prevalence of obesity was $38.6 \%$ [13]. Obesity has been linked to various chronic diseases and to the development of different types of cancer, including BC [14]. One study indicated that if the BMI had remained at 1982 levels, nearly a quarter (118,000 cases) of all obesity-related cancers in 2012 could have been avoided worldwide [15].

Obesity, as measured by BMI, has been associated with $\mathrm{BC}$ risk, but conflicting effects have been reported in premenopausal and postmenopausal women [16-19]. In premenopausal women, BMI is associated with decreased BC risk [20-27], whereas in postmenopausal women, it has been associated with an increased $\mathrm{BC}$ risk [28-30]. Recently, genetically predicted BMI was inversely associated with $\mathrm{BC}$ risk in both, premenopausal and postmenopausal women [31]. The mechanisms behind these associations have not been fully explained [27]. Several metabolic conditions associated with body fat can influence the $\mathrm{BC}$ risk differently in premenopausal and postmenopausal women [27, 32].

In a cohort study conducted in Swedish women, Tosovic et al. (2012) reported a positive association between serum concentrations of free T4 (FT4) and BC prior to diagnosis, particularly in women with a $\mathrm{BMI} \geq 25$, while for free T3 (FT3), the protective effect was higher in women with $\mathrm{BMI}<25$; however, most of the associations were not statistically significant [1]. White adipose tissue actively produces various hormones and cytokines (e.g., leptin and growth factors, among others) [33], which are important in the homeostasis and regulation of thyroid hormones [34]. Several studies in euthyroid women have reported that serum free thyroxine (FT4) concentration is inversely correlated with BMI [35-37], while FT3 has been positively associated with visceral fat [38, 39] and BMI $\geq 40$ [40], negatively with body fat measured using bioimpedance [41], and not correlated with BMI [36].

In the present case-control study, we examined the association between serum concentrations of thyroid hormones and BC in 2074 Mexican women who participated in the Cáncer de Mama (CAMA) study. We also examined obesity as an effect modifier of this relationship in premenopausal and postmenopausal women.

\section{Methods \\ Study population}

The present study is derived from the population-based case-control study "Risk factors for BC in Mexico: mammographic patterns, C-peptide, and growth factors, a multicenter study" (CAMA), which was conducted in three cities of Mexico (Monterrey, Veracruz, and Mexico City) from January 2004 to December 2007 [42]. In summary, the CAMA study included consecutive women with incident BC (cases $(n=1000)$ ), aged 35-69 years, who were required to have had a minimum of 5 years of residency in the study cities and who were recruited from 12 public hospitals (5 from the Mexican Social Security Institute (Instituto Mexicano de Seguro Social IMSS), 2 from the Institute of Security and Social Services of State Workers (Instituto de Seguridad y Servicios Sociales de los Trabajadores de Estado - ISSSTE), and 5 from the Ministry of Health (Secretaria de Salud - SS)). Nurses from the field staff were based at each hospital Monday to Friday from January 2004 to December 2007. The inclusion criteria for the cases were (a) histopathological confirmation of $\mathrm{BC}$ (median of 3 days between diagnosis and inclusion in the study); (b) no previous treatment (radiotherapy, chemotherapy, or antiestrogens) in the last 6 months; and (c) absence of pregnancy. The response rate of patients with BC was $94 \%$. Controls ( $n=1074)$ were selected based on a probabilistic multistage design and were randomly selected considering the catchment area of each of the participating hospitals. Mammography was performed and women with Breast Imaging Reporting and Data System (BI-RADS) categories I and II were included in the study. The response rate of controls was $87 \%$. The control group was matched to the patients according to quinquennial age, health 
institution affiliation, and state of residence. In-person interviews were conducted at the hospital with the patients and at the homes of the controls to obtain information on their sociodemographics, reproductive health, breast pathology, lifestyle, and co-morbidities. Information on the perception of body image in different stages of life (six stages) was also included. The perception was measured with the use of six pictograms that represent silhouettes from very thin to very obese. In both the patients and the controls, blood samples and anthropometric measurements were obtained at participating hospitals by personnel following standardized procedures and who were blinded to the study hypotheses. For the analyses of the present study, out of 1000 cases and 1070 controls we excluded 50 and 45 women, respectively, because they answered "yes" to the question "Has a doctor diagnosed you with thyroid disease?" In the remaining 950 cases and 1029 controls, we determined serum thyroid hormone concentrations in a random subsample of 645 cases, among whom $3 \%$ had in situ BC, and 697 controls (Fig. 1). Characteristics (e.g., age, residence, breastfeeding, first-degree BC family history, BMI, and parity) of the subsample and the total population from the CAMA study were not statistically different (data not shown).

\section{Blood measurements}

Blood samples were obtained from the participants after they had fasted for at least $8 \mathrm{~h}$. The samples were centrifuged at $3200 \mathrm{rpm}$ at room temperature for $15 \mathrm{~min}$, and the serum was separated and maintained at $-20{ }^{\circ} \mathrm{C}$ for 3 weeks and then at $-80{ }^{\circ} \mathrm{C}$ until use. Total concentrations of total T3 (TT3), total T4 (TT4), thyroid stimulating hormone (TSH), thyroglobulin (Tg), and thyroid peroxidase (TPO) and thyroglobulin ( $\mathrm{Tg}$ ) antibodies ( $\mathrm{TgAb}$ ) were determined in triplicate using a chemiluminescence assay in a Beckman Coulter UniCel DxI 800 system (Brea, CA, USA) according to the manufacturer's instructions. The coefficients of intra-assay and inter-assay variation were less than $6 \%$ for the hormones TT3, TT4, TSH, and Tg. In addition, at the Children's Hospital Oakland Research Institute, 106 ancestry information markers were genotyped using multiplex polymerase chain reaction (PCR) and Sequenom's

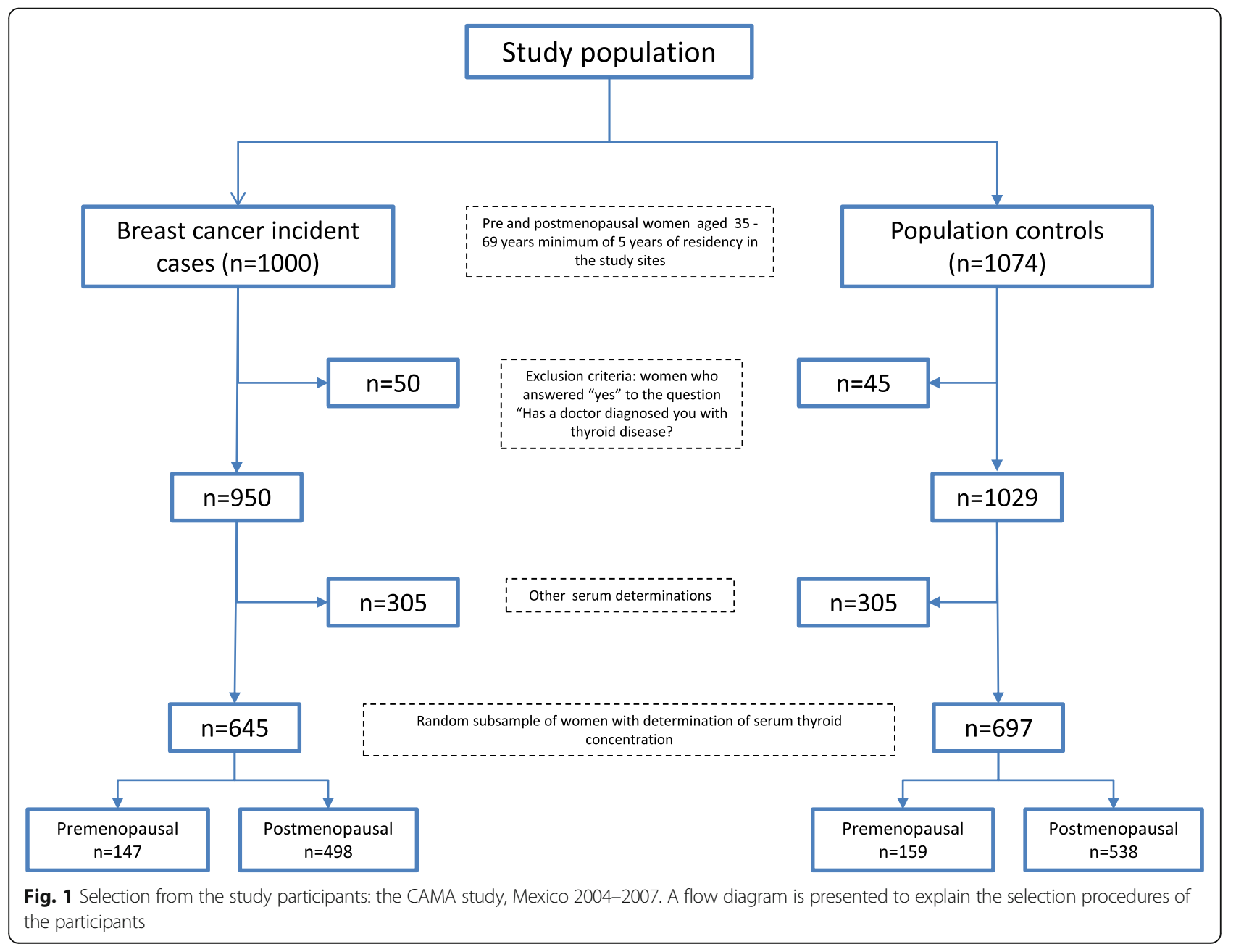


unique baseline extension methodology (Sequenom Inc., San Diego, CA, USA). The details of these markers have been published elsewhere [43, 44]. The laboratory personnel who performed the measurements were blinded to the condition (case or control) of each participant.

\section{Anthropometric measurements}

In order to obtain high-quality body measurements, trained nurses were assessed for intra-observer and inter-observer reliability until consistent and accurate anthropometric measurements were obtained. We used validated and standardized protocols and calibrated instruments according to Lohaman's recommendations [45]. Weight was measured using a digital scale (Tanita Corporation of America, Inc., Arlington Heights, IL, USA) and recorded to the nearest $0.1 \mathrm{~kg}$. Height was measured using a stadiometer (SECA, Hamburg, Germany) to the nearest millimeter. Waist circumference was measured at the level of the navel with the patient in standing position, and the hip circumference was measured at the most prominent level of the buttocks with the woman in a standing position. The BMI was calculated as the weight (in kilograms) divided by the height (in meters) squared. The waist-to-hip ratio (WHR) was calculated by dividing the waist circumference (in centimeters) by the hip circumference (in centimeters). The cutoff points used to estimate the association for BMI, waist circumference, hip circumference, and WHR were established according to the distribution of control patients into tertiles, while the cases were assigned according to the controls' cutoff points. Tertiles were used for the anthropometric variables because Mexican women are mostly in the overweight and obesity categories. In addition, the participating women were asked to select the silhouette that best represented their body shape (using six pictograms that represent body shape from very thin to extremely obese) at different stages of their lives (before and immediately after menarche, between 18 and 20 years of age, before their first pregnancy, between 25 and 35 years, and their current body shape at the time of the interview). The correlation between BMI and silhouette has been reported as 0.67 in adult women [46], and in the study population, the correlation was $p=0.69(p \leq 0.001)$. A trajectory analysis based on a group approach was performed as proposed by Nagin [47]; this approach is based on the identification of groups with different individual trajectories in the study population over time and looks for the most homogeneous clusters. To identify the optimal model (number of groups and trajectories), we used the Bayesian information criterion (BIC) $[47,48]$. To place enough subjects in each category for the statistical analysis, the body shape silhouettes were combined into categories. At childhood, at adolescence, at age 18-20 years, and at age before first pregnancy, the thin category included the women who selected silhouette 1 . Silhouette 2 was included for the median category, and for obesity, the women who selected silhouettes 3, 4, 5, and 6 were included. For body silhouettes of women aged 25-35 years and for their current body silhouette, the thin category included the women who selected silhouette 1 and 2. Silhouette 3 was included for the median category, and for obesity, the women who selected silhouettes 4, 5, and 6 were included [48].

\section{Diet}

A semi-quantitative Food Frequency Questionnaire (FFQ) adapted from Willett [49] to the Mexican population and validated in Mexico City [49, 50] was used for the present study. To measure caloric consumption, participants were asked to report frequency of consumption of a typical serving of 104 items in the past year, and responses were converted to average daily consumption. To calculate intakes, we used the nutrient database developed by the National Institute of Nutrition in Mexico [51] and, when necessary, the US Department of Agriculture food composition tables [52].

\section{Physical activity}

To measure physical activity, a semi-structured interview to estimate an individual's time spent performing different physical activities (sleep and light-, moderate-, and vigorous-intensity physical activity) was applied. The interview was based on the 7-day recall questionnaire proposed by Sallis et al. (1985) [53]. For the present study, weekly hours of moderate-intensity physical activity (activities that are tiresome but that do not result in breathlessness) were used. The patients were asked to report physical activity in a typical week 1 year before the appearance of signs and symptoms, to reduce the possibility of reverse causation bias, whereas the controls were asked to report physical activity for the year prior to the survey [42].

\section{Statistical analysis}

Descriptive statistics (medians, interquartile ranges, means, $\mathrm{SD}$ and proportions) were calculated for both the premenopausal and postmenopausal women who were categorized as either cases or controls. We described sociodemographic, reproductive health, anthropometry, breast pathology, lifestyle, comorbidities, thyroid function parameters and clinical characteristics of the patients (cases) in terms of clinical stage (early $\leq$ IIA; advanced $\geq$ IIB) and histological grade $(1,2$, or 3$)$.

To assess the association between $\mathrm{BC}$ and TT3 or TT4 serum concentrations, two logistic regression models were used, one for premenopausal and one for postmenopausal women. To build each model, bivariate 
models were constructed for each variable of interest and potential confounders, then variables with a $p$ value $\leq 0.20$ in the bivariate models were included in each final model. In order to build the most parsimonious models that still explain the data, we left the variables with a $p$ value $<0.05[54,55]$. The dependent variable was BC (yes/no), and the independent variables of interest were TT3 and TT4, which were incorporated into the models as standardized continuous variables $(\mathrm{Z}=(\mathrm{x}-\mu) / \sigma)$. For each model, odds ratios $(\mathrm{OR})$ and $95 \%$ confidence intervals $(95 \% \mathrm{CI})$ were obtained. For continuous variables such as thyroid function parameters and calorie consumption, we estimated the odds of $\mathrm{BC}$ for each increase in SD.

The following are the variables that were considered as potential confounders: (a) sociodemographic variables: age (years), entitlement to a health institution (IMSS, ISSSTE, and Ministry of Health), city of residence (Mexico City, Monterrey, or Veracruz), economic index (low, medium, or high), and educational level (last complete school grade); (b) reproductive health: age at menarche (years), age at menopause (years), time of exposure to endogenous hormones (age at menopause in years to age of menarche in years), parity (number of children born alive), ever use of hormonal contraception (yes/no), age at first full-term pregnancy (years), use of hormones for menopause for more than 1 month (yes/no), and breastfeeding (months); (c) anthropometric measurements: height $(\mathrm{cm})$; (d) breast pathology: personal history of benign breast disease (yes/ no) and family history of BC (mother, grandmother, or sisters) (yes/no); (e) lifestyles: hours of moderate-intensity physical activity per week [42, 53], alcohol consumption (consumed on average one or more alcoholic drinks a month for a year (yes/no)), tobacco consumption (smoked at least 100 cigarettes in her lifetime (yes/no), and daily calorie intake (Kcal) [49-52, 56]; (f) percentage of indigenous ancestry informative markers [44, 57]; (g) comorbidities: diabetes mellitus diagnosed by a physician (yes/ no); and (h) the other thyroid function parameters: TSH, $\mathrm{Tg}$, and $\mathrm{Tg}$ and thyroperoxidase TPO antibodies (TPO Ab) $(\mathrm{Z}=(\mathrm{x}-\mu) / \sigma)$. The percentage of ancestry informative markers was considered as a potential confounder due to its potential association with the thyroid hormone profile [57] and because it has been associated with BC [44].

The effect modification of obesity (BMI, waist circumference, hip circumference, WHR, and trajectories according to the silhouettes) was assessed for the association between TT3 or TT4 and BC in premenopausal and postmenopausal women. Multiplicative interactions were evaluated, which considered the thyroid hormones as continuous variables, the anthropometric variables in tertiles (waist circumference (tertiles), hip circumference (tertiles), BMI (tertiles), WHR (tertiles)), and the different trajectories of weight change (constantly low, constantly mid-range, moderate increase, strong increase, or constantly high). We focus our results on the potential effect modification by BMI since this variable has been associated more consistently as a protector against $\mathrm{BC}$ in premenopausal women and as a risk factor in postmenopausal women [23, 58-79]. The results for the rest of the anthropometric variables are presented in additional tables. Given that missing values were lower than $5 \%$, we did not include them in the analysis of multiple models. All models were then analyzed with goodness of fit, model specification, collinearity, and influential values tests according to the procedure proposed by Hosmer and Lemeshow [55]. The analysis was performed using the STATA v13 software (StataCorp, College Station, TX, USA).

\section{Results}

The characteristics of the study population are presented separately for premenopausal and postmenopausal women in Table 1. Compared to controls, premenopausal patients (cases), were more likely to have completed professional and postgraduate studies (data not shown). Among postmenopausal women, a higher percentage of patients completed secondary, high school, and postgraduate studies compared with the controls (data not shown). Parity, history of benign breast disease, physical activity, alcohol consumption, and history of diabetes mellitus are associated with $\mathrm{BC}$ according to the literature. In both premenopausal and postmenopausal women, waist circumference and hip circumference were smaller in the patients than in the controls. BMI was lower in the patients than in the controls. Table 2, shows that in both the premenopausal and postmenopausal women, the serum TT3 concentration was lower in the patients than in the controls, whereas the serum TT4 concentration was higher in the patients than in the controls. Table 3, shows that more than $40 \%$ of the study participants were diagnosed at an advanced clinical stage.

In the premenopausal women who were stratified by tertiles of the anthropometric variables (BMI, waist and hip measurements, and WHR), the median serum TT3 concentration was lower in the patients than in the controls, whereas TT4 concentrations were higher in the patients than in the controls, and serum TSH concentrations were similar in both groups. The same relationship was observed in postmenopausal women (data not shown).

Multiple models, minimally adjusted for age, health institution, and city of residence, showed that when all the women were analyzed, the serum concentration of the TT3 hormone was negatively associated with $\mathrm{BC}(\mathrm{OR}$ per standard deviation $=0.16,95 \% \mathrm{CI} 0.13-0.20$ ), and this association was maintained when the patients were stratified into the premenopausal $\left(\mathrm{OR}_{\text {per standard deviation }}=0.07,95 \% \mathrm{CI} 0.04-0.12\right)$ and postmenopausal groups $(\mathrm{OR}$ per standard deviation $=0.20$, 95\% CI 0.16-0.25) (data not shown). However, the 


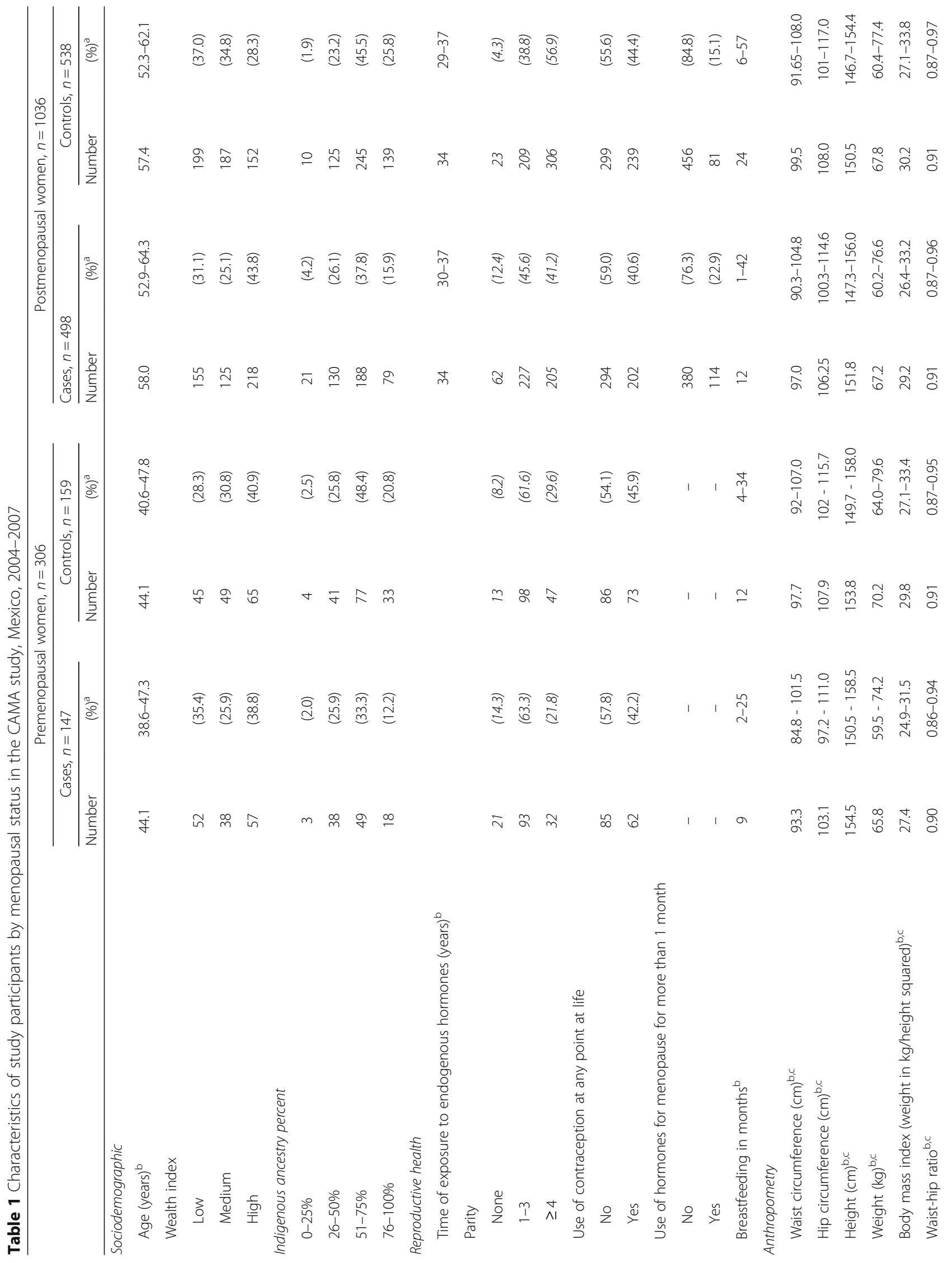




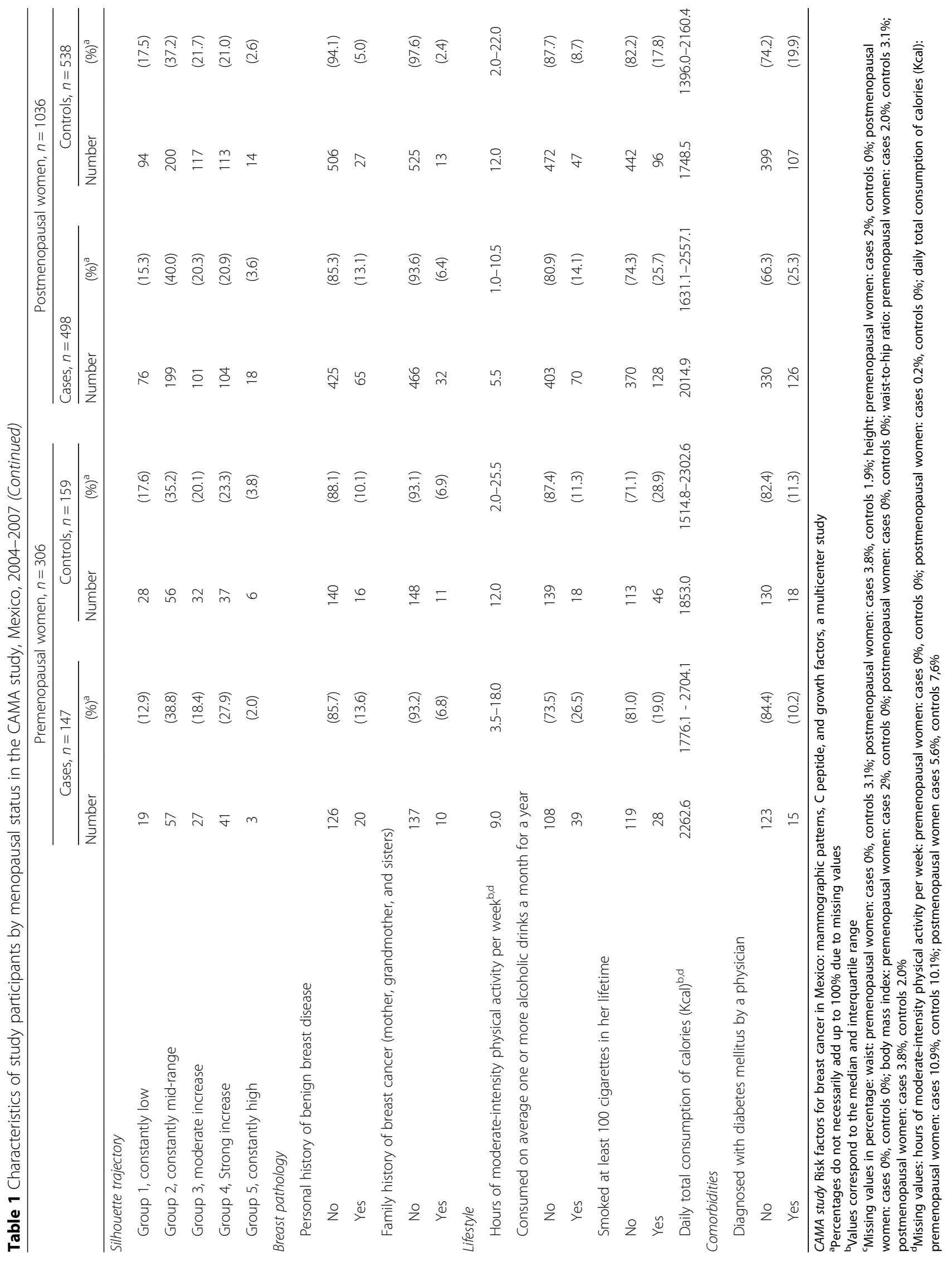


Table 2 Thyroid function parameters of study participants by menopausal status in the CAMA study, Mexico, 2004-2007

\begin{tabular}{|c|c|c|c|c|c|c|c|c|}
\hline & \multicolumn{4}{|c|}{ Premenopausal women, $n=306$} & \multicolumn{4}{|c|}{ Postmenopausal women, $n=1036$} \\
\hline & \multicolumn{2}{|c|}{ Cases, $n=147$} & \multicolumn{2}{|c|}{ Controls, $n=159$} & \multicolumn{2}{|c|}{ Cases, $n=498$} & \multicolumn{2}{|c|}{ Controls, $n=538$} \\
\hline & Median & $\begin{array}{l}\text { Interquartile } \\
\text { range }\end{array}$ & Median & $\begin{array}{l}\text { Interquartile } \\
\text { range }\end{array}$ & Median & $\begin{array}{l}\text { Interquartile } \\
\text { range }\end{array}$ & Median & $\begin{array}{l}\text { Interquartile } \\
\text { range }\end{array}$ \\
\hline \multicolumn{9}{|l|}{ Thyroid function parameters } \\
\hline Total triiodotyronine (TT3) nmol/ $\mathrm{L}^{\mathrm{a}}$ & 1.6 & $1.3-1.9$ & 2.4 & $1.9-2.8$ & 1.7 & $1.4-2.1$ & 2.6 & $2.1-3.0$ \\
\hline Mean (SD) & 1.7 & 0.5 & 2.4 & 0.6 & 1.8 & 0.7 & 2.6 & 0.6 \\
\hline Total thyroxin (TT4) nmol/ $\mathrm{L}^{\mathrm{a}}$ & 103.4 & $87.4-123.1$ & 93.1 & $83.7-109.7$ & 104.6 & $89.8-122.3$ & 96.7 & $84.4-112.2$ \\
\hline Mean (SD) & 107.3 & 27.3 & 97.2 & 22 & 108.6 & 29.5 & 100.5 & 25.7 \\
\hline $\mathrm{TSH} \mu \mathrm{UI} / \mathrm{mL}^{\mathrm{a}}$ & 1.6 & $1.1-2.1$ & 1.7 & $1.1-2.3$ & 1.8 & $1.1-2.8$ & 1.8 & $1.1-2.9$ \\
\hline Mean (SD) & 1.8 & 1.4 & 2.3 & 3.3 & 2.9 & 9.6 & 2.9 & 6.8 \\
\hline Thyroglobulin ng/mL ${ }^{a}$ & 6.4 & $4.0-10.2$ & 7.1 & $4.5-12.2$ & 7.4 & $3.9-14.5$ & 7.4 & $4.0-14.5$ \\
\hline Mean (SD) & 8.9 & 9.3 & 9.9 & 10.9 & 17.8 & 70.1 & 15.9 & 47.1 \\
\hline Anti-peroxidase antibodies $\mathrm{UI} / \mathrm{mL}^{\mathrm{b}}$ & 0.1 & $0.5-2.5$ & 1.10 & $0.6-3.1$ & 1.1 & $0.6-3.9$ & 1.1 & $0.6-3.5$ \\
\hline Mean (SD) & 46.4 & 266.2 & 222.3 & 1373.8 & 111.1 & 444.6 & 95.0 & 346.3 \\
\hline \multicolumn{9}{|l|}{ Anti-thyroglobulin antibodies ${ }^{b, c}$} \\
\hline Negative & 73 & $(49.7)$ & 59 & $(37.1)$ & 135 & $(27.1)$ & 133 & $(24.7)$ \\
\hline Positive & 71 & $(48.3)$ & 100 & $(62.9)$ & 221 & $(44.4)$ & 240 & $(44.6)$ \\
\hline $\begin{array}{l}\text { Median UI/mL (interquartile } \\
\text { range) })^{d}\end{array}$ & 0.9 & $0.3-3.1$ & 1.0 & $0.04-3.0$ & 1.0 & $0.3-4.6$ & 0.8 & $0.4-2.8$ \\
\hline Mean $(S D)^{d}$ & 17.7 & 106.4 & 4.7 & 9.8 & 23.1 & 165.1 & 14.4 & 102.4 \\
\hline
\end{tabular}

CAMA study Risk factors for breast cancer in Mexico: mammographic patterns, C peptide, and growth factors, a multicenter study, TSH thyroid stimulating hormone

a There are no missing values for $\Pi 3, \pi 4, \mathrm{TSH}$ and thyroglobulin

${ }^{\mathrm{b}}$ Results correspond to 147 cases and 159 controls (premenopausal women), respectively; and to 356 cases and 373 controls (postmenopausal)

cNumber and (percentage) of women with negative/positive anti-thyroglobulin antibodies

${ }^{\mathrm{d}}$ The values correspond to women with positive results for anti-thyroglobulin antibodies

protective effect was much higher in premenopausal than in postmenopausal women. The association between serum TT4 concentration and $\mathrm{BC}$ was positive when all the women were analyzed $(\mathrm{OR}$ per standard deviation $=1.71,95 \% \mathrm{CI}$ 1.48-1.98), and this association was maintained when the patients were stratified by menopausal status; however, stronger association was seen in premenopausal women $(\mathrm{OR}$ per standard deviation $=1.97,95 \%$ CI $1.38-2.82)$ compared with postmenopausal women $(\mathrm{OR}$ per standard deviation $=1.71$, 95\% CI 1.48-1.98) (data not shown). No significant associations were found with any other thyroid function parameters (TSH, Tg, Tg Ab, or TPO Ab).

Table 4 presents the multiple model stratified by menopausal status, adjusted by BMI and Table 5 presents the models stratified by both menopausal status and BMI. In Table 4, a negative association was

Table 3 Clinical characteristics of patients with breast cancer (cases) by menopausal status in the CAMA study, Mexico, 2004-2007

\begin{tabular}{|c|c|c|c|c|}
\hline & \multicolumn{2}{|c|}{ Premenopausal cases, $n=147$} & \multicolumn{2}{|c|}{ Premenopausal cases, $n=498$} \\
\hline & Number & Percentage $^{a}$ & Number & Percentage $^{a}$ \\
\hline \multicolumn{5}{|l|}{ Clinical characteristics } \\
\hline \multicolumn{5}{|l|}{ Clinical stage } \\
\hline Early $(\leq \| \mathrm{A})$ & 43 & $(29.3)$ & 175 & $(35.1)$ \\
\hline Advanced ( $\geq \| \mathrm{B})$ & 73 & $(49.7)$ & 206 & $(41.4)$ \\
\hline \multicolumn{5}{|l|}{ Histological grade } \\
\hline 1 & 4 & $(2.7)$ & 8 & (1.6) \\
\hline 2 & 29 & $(19.7)$ & 108 & $(21.7)$ \\
\hline 3 & 9 & (6.1) & 49 & (9.8) \\
\hline
\end{tabular}

CAMA study Risk factors for breast cancer in Mexico: mammographic patterns,

$C$ peptide, and growth factors, a multicenter study

apercentages do not add up to $100 \%$ due to missing values 
Table 4 Associations between thyroid function tests and breast cancer adjusted by BMI in the CAMA study, Mexico, 2004-2007

\begin{tabular}{|c|c|c|c|c|c|c|}
\hline & \multicolumn{3}{|c|}{ Premenopausal women $^{a}$} & \multicolumn{3}{|c|}{ Postmenopausal women ${ }^{b}$} \\
\hline & case/control & OR & $95 \% \mathrm{Cl}$ & case/control & OR & $95 \% \mathrm{Cl}$ \\
\hline$\pi 3^{c}$ & $128 / 142$ & 0.03 & $0.01-0.07$ & $382 / 498$ & 0.17 & $0.13-0.22$ \\
\hline$\pi 4^{c}$ & & 5.98 & $3.01-11.90$ & & 2.81 & $2.17-3.65$ \\
\hline \multicolumn{7}{|l|}{$\mathrm{BMI}$} \\
\hline Tertile 1 (BMI < 27.88) & $67 / 47$ & 1.00 & & $145 / 166$ & 1.00 & \\
\hline Tertile 2 (BMI 27.88-32.05) & $35 / 48$ & 0.56 & $0.23-1.37$ & $106 / 168$ & 0.98 & $0.63-1.52$ \\
\hline Tertile 3 (BMI $\geq 32.06$ ) & $26 / 47$ & 0.28 & $0.11-0.75$ & $131 / 164$ & 1.16 & $0.75-1.80$ \\
\hline
\end{tabular}

CAMA study Risk factors for breast cancer in Mexico: mammographic patterns, $\mathrm{C}$ peptide, and growth factors, a multicenter study. $\pi 3$ total triiodothyroxine, $\Pi 44$ total thyroxine, $B M I$ body mass index

${ }^{a}$ Logistic regression model in premenopausal women: dependent variable, breast cancer (yes/no); independent variables, TT3 (nmol/L) and TT4 (nmol/L); potential confounders, age (years), city of residence (Mexico City (reference category), Veracruz and Monterrey), health institution (IMSS: Mexican Social Security Institute (reference category); ISSSTE: Institute of Security and Social Services of State Workers; SS: Ministry of Health), daily total consumption of calories (Kcal) and BMI (tertiles). Hormone concentrations and calorie consumption were standardized to allow interpretation of the odds of breast cancer development per increment of standard deviation, $\mathrm{Z}=(\mathrm{x}-\mu) / \sigma$

${ }^{b}$ Logistic model in postmenopausal women: dependent variable, breast cancer (yes/no); independent variables, $\Pi T 3$ (nmol/L) and $\Pi \pi 4$ (nmol/L); potential confounders: age (years), city of residence (Mexico City (reference category), Veracruz and Monterrey), health institution (IMSS: Mexican Social Security Institute (reference category); ISSSTE: Institute of Security and Social Services of State Workers; SS: Ministry of Health), thyroid stimulating hormone (continuous), parity (continuous), consumed on average one or more alcoholic drinks a month for a year (yes/no) and smoked at least 100 cigarettes in her lifetime (yes/no), indigenous ancestry (continuous) and BMI (tertiles). Hormone concentrations and calorie consumption were standardized to allow interpretation of the odds of breast cancer development per increment of standard deviation, $\mathrm{Z}=(\mathrm{x}-\mu) / \sigma$

'TT3 (mean 1.7 SD 0.5); TT4 (mean 103.4 SD 27.3)

observed between the serum TT3 concentration and $\mathrm{BC}$ in both premenopausal and postmenopausal women, and a positive association was observed between the serum TT4 concentration and BC. The association was stronger in premenopausal women than in postmenopausal women for both hormones. These associations were similar when each of the remaining anthropometric variables and the trajectory of the silhouettes were independently adjusted (Additional file 1: Table S1).

Table 5 Association between thyroid function tests and breast cancer modified by obesity in the CAMA study, Mexico, 2004-2007

\begin{tabular}{|c|c|c|c|c|c|c|}
\hline & \multicolumn{3}{|c|}{ Premenopausal women $^{\mathrm{a}}$} & \multicolumn{3}{|c|}{ Postmenopausal women $^{\mathrm{b}}$} \\
\hline & Case/control & OR & $95 \% \mathrm{Cl}$ & Case/control & OR & $95 \% \mathrm{Cl}$ \\
\hline \multicolumn{7}{|c|}{ Multiple model stratified by BMI tertiles } \\
\hline Tertile 1 (BMl < 27.88) & $67 / 47$ & & & $145 / 166$ & & \\
\hline$\pi 3^{c}$ & & 0.02 & $0.003-0.09$ & & 0.18 & $0.11-0.28$ \\
\hline$\pi 4^{c}$ & & 11.97 & $3.43-41.80$ & & 2.62 & $1.67-4.09$ \\
\hline Tertile 2 (BMI 27.88-32.05) & $35 / 48$ & & & 106/168 & & \\
\hline$\pi 3^{c}$ & & 0.04 & $0.0-0.16$ & & 0.15 & $0.09-0.25$ \\
\hline$\pi 4^{c}$ & & 8.34 & $2.03-34.24$ & & 3.03 & $1.83-5.02$ \\
\hline Tertile 3 (BMI $\geq 32.06$ ) & $26 / 47$ & & & $131 / 164$ & & \\
\hline$\pi 3^{c}$ & & 0.01 & $0.0004-0.08$ & & 0.10 & $0.06-0.18$ \\
\hline$\pi 4^{c}$ & & 2.23 & $0.39-12.66$ & & 3.52 & $2.15-5.75$ \\
\hline \multicolumn{3}{|c|}{$p$ value for interaction between $T T 4$ and $\mathrm{BMI}$ tertiles } & 0.22 & & & 0.059 \\
\hline \multicolumn{3}{|c|}{$p$ value for interaction between $T T 3$ and $\mathrm{BMI}$ tertiles } & 0.12 & & & 0.34 \\
\hline
\end{tabular}

CAMA study Risk factors for breast cancer in Mexico: mammographic patterns, peptide $C$, and growth factors, a multicenter study, $B M I$ body mass index, $\Pi \pi 3$ total triiodothyroxine, $\Pi 4$ total thyroxine

${ }^{a}$ Logistic regression model in premenopausal women: dependent variable, breast cancer (yes/no); independent variables, $\Pi 3$ ( $\mathrm{nmol} / \mathrm{L}$ ) and $\Pi 4$ (nmol/L); potential confounders, age (years), city of residence (Mexico City (reference category) Veracruz and Monterrey), health institution (IMSS: Mexican Social Security Institute (reference category); ISSSTE: Institute of Security and Social Services of State Workers; SS: Ministry of Health), daily total consumption of calories (Kcal). Models are presented by each tertile of BMI. Hormone concentrations and calorie consumption were standardized to allow interpretation of the odds of breast cancer development per increment of standard deviation, $Z=(x-\mu) / \sigma$

bLogistic regression model in postmenopausal women: dependent variable, breast cancer (yes/no); independent variables, TT3 (nmol/L) and TT4 (nmol/L); potential confounders: age (years), city of residence (Mexico City (reference category) Veracruz and Monterrey), health institution (IMSS: Mexican Social Security Institute (reference category); ISSSTE: Institute of Security and Social Services of State Workers; SS: Ministry of Health), thyroid stimulating hormone (continuous), parity (continuous), consumed on average one or more alcoholic drinks a month for a year (yes/no) and smoked at least 100 cigarettes in her lifetime (yes/no) and indigenous ancestry (continuous). Models are presented by each tertile of BMI. Hormone concentrations and calorie consumption were standardized to allow interpretation of the odds of breast cancer development per increment of standard deviation, $\mathrm{Z}=(\mathrm{x}-\mu) / \sigma$

${ }^{\top} \mathrm{T} T 3$ (mean 1.7 SD 0.5); $T$ 4 (mean 103.4 SD 27.3) 
When premenopausal women were stratified by BMI (Table 5), it was observed that the association between the serum concentration of TT4 and BC decreased as BMI tertiles increased, until they were no longer significant in the upper tertile ( $p$ of interaction $=0.22$ ), while the protective effect of the serum TT3 concentration was maintained in the three tertiles ( $p$ of interaction $=0.12$ ). Similarly, the effects of the serum concentrations of TT3 and TT4 were evaluated based on the remainder of the anthropometric variables, and waist circumference $(p=0.887)$, hip circumference $(p=0.291)$, WHR $(p=0.381)$, and the silhouettes trajectory variable $(p=0.52)$ were not statistically significant (Additional file 1: Table S2). In postmenopausal women, stratification by BMI showed that the association between the serum TT4 concentration and BC increased as the BMI tertiles increased ( $p$ of interaction $=0.059)($ Table 5$)$. For the other anthropometric variables, potential effect modification was observed with hip circumference (tertile $1, \mathrm{OR}=2.17$, CI 1.34-3.50; tertile 2, $\mathrm{OR}=3.58$. CI 2.16-5.95; tertile 3 , $\mathrm{OR}=3.47$, CI $2.12-5.68, p$ of interaction $=0.02$ ), with WHR (tertile $1, \mathrm{OR}=2.97, \mathrm{CI} 1.84-4.80$; tertile 2, $\mathrm{OR}=4.43$. CI 2.38-8.27; tertile 3 , $\mathrm{OR}=2.46$, CI 1.60-3.80, $p$ of interaction $=0.02$ ), and with the silhouettes trajectory (constantly low, $\mathrm{OR}=3.87$, CI $1.72-8.73$; constantly mid-range, $\mathrm{OR}=2.12$, CI 1.44-3.13; moderately increased, $\mathrm{OR}=2.53$, CI 1.37-4.66; strong increase, $\mathrm{OR}=4.57, \mathrm{CI}$ $2.38-8.86, p$ of interaction $=0.02$ ), but an effect modification was not observed with waist circumference ( $p$ of interaction $=0.51$ ). The interactions between the serum TT3 concentration and the anthropometric variables were also evaluated, but these were not statistically significant for BMI $(p=0.34)$, hip circumference $(p=0.49)$, waist circumference $(p=0.74)$, WHR $(p=0.38)$, or the silhouettes trajectory $(p=0.36)$ (Additional file 1: Table S2).

\section{Discussion}

The addition of $\mathrm{T} 4$ to $\mathrm{BC}$-derived cell lines has been shown to increase cell proliferation [3], while in the presence of estrogen receptor (ER)-positive $\mathrm{BC}$ cell lines the addition of T3 inhibits cell proliferation [7]. These effects are important, as abnormalities in thyroid function tests have been observed in a variety of nonthyroidal illness, without preexisting thyroid or hypothalamic-pituitary disease, including BC [80]. These abnormalities might change by BMI because thyroid hormones are involved in the regulation of various metabolic pathways that are relevant for resting energy expenditure [10, 11]. They could also change by menopausal status because obesity has been negatively associated with $\mathrm{BC}$ in premenopausal women [20-27] and has been positively associated with $\mathrm{BC}$ in postmenopausal women [30]. It is important to assess the modifying effect of obesity in this association because of the implications for treatment in populations in where the prevalence of obesity and thyroid dysfunction is high.

We analyzed the association between thyroid hormones and $\mathrm{BC}$ and the modification effects of general obesity (BMI), central or intra-abdominal obesity (waist circumference, hip circumference, and waist-hip ratio), and trajectories of change in body shape. Initially, we observed that in both the premenopausal and postmenopausal women, the serum TT4 concentration was positively associated with $\mathrm{BC}$, whereas the serum TT3 concentration was inversely associated with $\mathrm{BC}$. These associations were stronger in the premenopausal women. When the premenopausal women were stratified by BMI tertiles, the positive association between the serum TT4 concentration and $\mathrm{BC}$ decreased as the BMI tertiles increased; this association was no longer statistically significant in the highest tertile, probably due to the smaller sample size. In contrast, for the postmenopausal women in the highest tertile of BMI, the strength of the association between the serum TT4 concentration and $\mathrm{BC}$ was increased.

A possible explanation for our findings could be related to the difference between premenopausal and postmenopausal women with respect to the possibility or risk of the development of ER-negative (ER-) BC due to BMI [81] and due to the finding that the maintenance of increased cell proliferation caused by T4 requires ER function [82]. Studies that have investigated the association between BMI and different molecular subtypes have suggested that in premenopausal women with a $B M I \geq 25$, the prevalence of luminal tumors (ER positive $(\mathrm{ER}+)$ or progesterone receptor-positive $(\mathrm{PR}+))$, human epidermal growth factor receptor 2 positive or negative (HER2+ or HER2-) and triple-negative tumors (ER-, PR-, HER2-) is higher than in those with a BMI < 25 [83]. Harris et al. (2011) consistently showed that in this same group of women, the risk of development of ER- BC was higher in those in the upper quintiles of waist and hip circumference and of WHR than in those in the lower quintile [27]. In contrast, in postmenopausal women, compared with women with a BMI $<25$, the possibility of the development of luminal $\mathrm{BC}$ was greater in those with a BMI $\geq 25$ [83]. Additionally, a pooled analysis of 35,568 women with invasive $\mathrm{BC}$ who participated in 34 studies showed that in those $\leq 50$ years of age, the likelihood of observing ER- tumors was higher in obese women $\left(B M I \geq 30 \mathrm{~kg} / \mathrm{m}^{2}\right)$ than in women who were not obese (BMI $<25 \mathrm{~kg} / \mathrm{m}^{2}$ ), and this association was statistically significant [81]. This same association was not statistically significant in women $>50$ years of age [81].

Tang et al. observed that both the T4 hormone and $17 \beta$-estradiol (E2) promoted cell proliferation through the stimulation of the mitogen-activated protein kinase (MAPK) pathway by ER and demonstrated that such proliferation requires ER function to be sustained [82]. 
In several cell models, it has been observed that at physiological concentrations, T4 is more active than T3 at stimulating the MAPK pathway [84-87]. In premenopausal women, the decrease in the association between TT4 and BC with increasing BMI could be explained by the lower prevalence of ER+ tumors in overweight and obese women [88, 89]. In contrast, in postmenopausal women, the increase in the association between $\mathrm{T} 4$ and $\mathrm{BC}$ with increasing BMI may be explained by the finding that overweight and obese women are at a greater risk of the development of ER+ breast tumors. However, more studies need to be performed stratifying by menopausal status and BMI. Two cohort studies reported a positive association between the serum T4 concentration and BC. However, in the aforementioned studies no effect modification was assessed for BMI and menopausal status [1, 90].

In our study we observed a negative association between serum TT3 and BC in both premenopausal and postmenopausal women. On the other hand, we did not observe an effect modification of this association by BMI. In addition, our results are consistent with previously published studies. For example, in studies of ER- cell lines that were transfected with ER, T3 inhibited cell proliferation [7]. Also, Tosovic et al., reported a non-statistically significant negative association between serum T3 and BC, independently of menopausal status [1]. That group also observed a negative association when women were stratified by menopausal status and BMI; however, it was not statistically significant [1].

The findings that we report need to be interpreted within the context of certain limitations. The number of premenopausal women was not sufficient for the identification of a statistically significant effect modification by BMI or other obesity measurements; moreover, the confidence intervals after stratification were broad, particularly for other anthropometric measurements that are presented in additional tables. Given the characteristics of Mexican women, among whom more than $70 \%$ were overweight and obese, it was not possible to use the cutoff points proposed by the WHO for anthropometric measurements; hence, we stratified the controls by tertiles for each measurement. Our study personnel were trained to measure weight and height and the other anthropometric variables using a standardized approach in both cases and controls, and in the cases, the measurements were performed at the time of the diagnosis. As BMI can be modified by the presence of cancer, this study is not free of reverse causality. However, the median number of days from the diagnosis until the women entered the study and the anthropometric variables were determined was 3 days. Additionally, we measured TT4. Free T4 (FT4) is unbound and is the active component of TT4, therefore further studies should be performed using FT4. Approximately $75 \%$ of the T4 in serum is bound to thyroid-binding globulin (TBG), and a smaller fraction is bound to transthyretin or albumin; so less than $0.1 \%$ remains free or unbound [91]. Given that postmenopausal hormone therapy and the use of hormonal contraceptives at any point in life lead to increased thyroid binding globulin (TBG) binding capacity [92], we considered adjusting for these variables in our models. However, we did not include them in the final models because they did not confound our main results. We did not include the ER status because when recruiting the patients (cases), ER status was not determined in all women. Tosovic et al., (2014) found statistically significant positive associations between higher pre-diagnostic T3 concentration and negative ER status [93]. However, further analysis needs to be performed because the sample size was very small and they did not adjust or stratify by BMI.

Our findings are congruent with previously observed altered T3 and T4 measurements in diseases such as BC [9]. In those circumstances, there is dysregulation of thyrotrophic feedback control [9], in which T3 and/or $\mathrm{T} 4$ are at unusual levels, but the thyroid gland does not appear to be dysfunctional. Thus, the lower levels of T3 and higher levels of $\mathrm{T} 4$ in $\mathrm{BC}$ cases may be due to the effect of $\mathrm{BC}$ on thyroid function rather than $\mathrm{T} 3$ and $\mathrm{T} 4$ acting as risk factors for BC. If so, these findings may still be of interest to understand whether the levels of T3 and T4 could be related to tumor stage or have other implications for prognosis.

Our findings need to be replicated in other studies, including those with larger sample sizes and to investigate other possible mechanisms by which the association between $\mathrm{T} 4$ and $\mathrm{BC}$ is potentially modified by BMI in premenopausal and postmenopausal women. In particular, prospective cohort studies in which T3 and T4 are collected prior to cancer diagnosis may be helpful in understanding the causal relationship between $\mathrm{BC}$ and thyroid hormones. In addition, a prospective study may also help to improve understanding of the relationship among thyroid hormones, $\mathrm{BC}$, and obesity.

To the best of our knowledge, this is the first study that has evaluated the effect modification by BMI of the relationship between thyroid hormones and $\mathrm{BC}$, both in premenopausal and postmenopausal women. The results of the present study open a new line of research with which to evaluate the effect modification by obesity of the association between thyroid hormones and BC.

\section{Conclusions}

There is a strong association between $\mathrm{BC}$ and serum concentrations of TT3 and TT4; the latter differed by BMI and menopausal status. This needs to be further investigated to understand why it happens and how important it is to consider these alterations in treatment. 


\section{Additional file}

Additional file 1: Table S1. Associations between thyroid function tests and BC adjusted by anthropometric variables. CAMA Study', Mexico 20042007. The table presents the multiple model stratified by menopausal status, adjusted by hip and waist measurements, WHR, and trajectory of the silhouettes. Table S2. Association between thyroid function tests and BC modified by anthropometric variables. CAMA Study ${ }^{1}$, Mexico 2004-2007. The table presents the multiple model stratified by menopausal status, and each of anthropometric variables (hip and waist measurements, WHR, and trajectory of the silhouettes). (DOCX $30 \mathrm{~kb}$ )

\section{Abbreviations}

BC: Breast cancer; bFGF: Fibroblast growth factor; BIC: Bayesian information criterion; BMl: Body mass index; CAMA: Risk factors for breast cancer in Mexico: mammographic patterns, $C$ peptide, and growth factors, a multicenter study; E2: 17ß-estradiol; ER: Estrogen receptor; FT3: Free triiodothyronine; FT4: Free thyroxine; HER2: Human epidermal growth factor receptor 2; IMSS: Instituto Mexicano de Seguro Social; ISSSTE: Instituto de Seguridad y Servicios Sociales de los Trabajadores del Estado; MAPK: Mitogen-activated protein kinase; OR: Odds ratio; PR: Progesterone receptor; RIC: Interquartile range; SS: Secretaría de Salud; T3: Triiodothyronine; T4: Thyroxine; TBG: Thyroid binding globulin; Tg: Thyroglobulin; Tg Ab: Thyroglobulin antibodies; TPO Ab: Thyroperoxidase antibodies; TSH: Thyroid stimulating hormone; TT3: Total triiodothyronine; TT4: Total thyroxine; VEGF: Vascular endothelial growth factor; WHO: World Health Organization; WHR: Waist-to-hip ratio

\section{Acknowledgments}

We would like to acknowledge CONACyT (CONACyT-SALUD-2002 C01-7462) y DGPOP 2011 (Dirección General de Programación Organización y Presupuesto, Ejercicio fiscal 2011, Ramo 12 Salud) for the financial support provided for this work and all physicians responsible for the project in the different participating hospitals: Dr Germán Castelazo (IMSS, Ciudad de México, DF), Dr Sinhué Barroso Bravo (IMSS, Ciudad de México, DF), Dr Joaquín Zarco Méndez (ISSSTE, Ciudad de México, DF), Dr Jesús Pablo Esparza Cano (IMSS, Monterrey, Nuevo León), Dr Heriberto Fabela (IMSS, Monterrey, Nuevo León), Dr Fausto Hernández Morales (ISSSTE, Veracruz, Veracruz), Dr Pedro Coronel Brizio (CECAN SS, Xalapa, Veracruz) and Dr Vicente A Saldaña Quiroz (IMSS, Veracruz, Veracruz).

\section{Funding}

This work was funded by the National Council of Science and Technology (grant CONACyT-SALUD-2002 C01-7462) and DGPOP 2011, Dirección General de Programación Organización y Presupuesto, Ejercicio fiscal 2011, Ramo 12 Salud.

\section{Availability of data and materials}

The datasets generated and/or analyzed during the current study are available from the corresponding author on reasonable request.

\section{Authors' contributions}

COO and GTM conceived the study, interpreted the data, and wrote the manuscript. COO, GTM, and AALL were involved with collection of data. COO carried out all data analysis. FMR and EPR facilitated the contact with patients. COO, AUA, AALL, FMR, CEGA, MLHB, EZ, LAS, EPR, and GTM were all involved in data interpretation, critical revisions of the manuscript, and approval of the final version.

\section{Ethics approval and consent to participate}

All participants in the study had provided written informed consent and the study was approved by the ethics and research committees of the National Institute of Public Health (Instituto Nacional de Salud Pública) (number Cl-349).

\section{Consent for publication}

\section{Not applicable.}

\section{Competing interests}

The authors declare that they have no competing interests.

The views expressed in this manuscript are those of the authors and do not necessarily represent the views of the National Heart, Lung, and Blood Institute; the National Institutes of Health; or the U.S. Department of Health and Human Services.

\section{Publisher's Note}

Springer Nature remains neutral with regard to jurisdictional claims in published maps and institutional affiliations.

\section{Author details}

${ }^{1}$ Universidad Autónoma de San Luis Potosí, Facultad de Enfermería y Nutrición, Niño Artillero \#130, Zona Universitaria, C.P. 78240 San Luis Potosí, S.L.P., México. ${ }^{2}$ Red de Apoyo a la Investigación, Universidad Nacional Autónoma de México-Instituto Nacional de Ciencias Médicas y Nutrición Salvador Zubirán, calle Vasco de Quiroga No. 15, Col. Belisario Domínguez Sección XVI, Del. Tlalpan, C.P. 14080 Ciudad de México, México. ${ }^{3}$ Centro de Investigación en Salud Poblacional, Instituto Nacional de Salud Pública, Av. Universidad No. 655, Col. Santa María Ahuacatitlán, Cuernavaca C.P. 62100, Morelos, México. ${ }^{4}$ Hospital de Ginecología y Obstetricia No. 4 Luis Castelazo Ayala, Instituto Mexicano del Seguro Social, Avenida Río Magdalena No. 289, Col. Tizapán, San Angel, Ciudad de México C.P. 01090, México. ${ }^{5}$ Department of Medicine, Division of General Internal Medicine, Institute for Human Genetics, Helen Diller Family Comprehensive Cancer Center, University of California, San Francisco, 1450 3rd St, San Francisco, CA 94143, USA. ${ }^{6}$ Department of Epidemiology and Biostatistics, Helen Diller Family Comprehensive Cancer Center, University of California, San Francisco, 1450 3rd St, San Francisco, CA 94143, USA. ${ }^{7}$ National Heart, Lung, and Blood Institute at the National Institutes of Health, 6701 Rockledge, Room 10188, Bethesda, MD 20892, USA. ${ }^{8}$ Hospital Universitario "Dr José Eleuterio González". Madero y Dr. Aguirre Pequeño, Col. Mitras, C.P. 64460 Monterrey, N.L., México. ${ }^{9}$ Instituto Nacional de Salud Pública, Centro de Investigación en Salud Poblacional, Avenida Universidad 655, Col. Santa María Ahuacatitlán, C.P. 62100 Cuernavaca, Morelos, México.

Received: 9 February 2018 Accepted: 10 July 2018

Published online: 09 August 2018

\section{References}

1. Tosovic A, Becker C, Bondeson AG, Bondeson L, Ericsson UB, Malm J, et al. Prospectively measured thyroid hormones and thyroid peroxidase antibodies in relation to breast cancer risk. Int J Cancer. 2012;131:2126-33.

2. Tosovic A, Bondeson AG, Bondeson L, Ericsson UB, Malm J, Manjer J. Prospectively measured triiodothyronine levels are positively associated with breast cancer risk in postmenopausal women. Breast Cancer Res. 2010;12:R33.

3. Davis PJ, Goglia F, Leonard JL. Nongenomic actions of thyroid hormone. Nat Rev Endocrinol. 2016;12:111-21.

4. Meng R, Tang HY, Westfall J, London D, Cao JH, Mousa SA, et al. Crosstalk between integrin alphavbeta3 and estrogen receptor-alpha is involved in thyroid hormone-induced proliferation in human lung carcinoma cells. PLoS One. 2011;6:e27547.

5. Lin HY, Sun M, Tang HY, Lin C, Luidens MK, Mousa SA, et al. L-thyroxine vs. 3,5,3'-triiodo-L-thyronine and cell proliferation: activation of mitogenactivated protein kinase and phosphatidylinositol 3-kinase. Am J Physiol Cell Physiol. 2009;296:C980-91.

6. Nogueira CR, Brentani MM. Triiodothyronine mimics the effects of estrogen in breast cancer cell lines. J Steroid Biochem Mol Biol. 1996;59:271-9.

7. Cestari SH, Figueiredo NB, Conde SJ, Clara S, Katayama ML, Padovani CR, et al. Influence of estradiol and triiodothyronine on breast cancer cell lines proliferation and expression of estrogen and thyroid hormone receptors. Arq Bras Endocrinol Metabol. 2009;53:859-64.

8. Hall LC, Salazar EP, Kane SR, Liu N. Effects of thyroid hormones on human breast cancer cell proliferation. J Steroid Biochem Mol Biol. 2008;109:57-66.

9. Mclver B, Gorman CA. Euthyroid sick syndrome: an overview. Thyroid. 1997; 7:125-32.

10. Reinehr T. Obesity and thyroid function. Mol Cell Endocrinol. 2010;316:165-71.

11. Longhi S, Radetti G. Thyroid function and obesity. J Clin Res Pediatr Endocrinol. 2013;5(Suppl 1):40-4.

12. Obesity and overweight. 2018. [http://www.who.int/mediacentre/factsheets/ fs311/en/]. Accessed 19 July 2018.

13. Hernández Ávila M, Rivera Dommarco J, Shamah Levy T, Cuevas Nasu L, Gómez Acosta L, Gaona Pineda E, Romero Martínez M, Méndez Gómez-Humarán I, Saturno Hernández P, Villalpando Hernández S, et al. Encuesta Nacional de Salud y Nutrición de Medio Camino 2016 (ENSANUT 2016). Instituto Nacional de Salud Pública; 2016. http://promocion.salud.gob.mx/dgps/descargas1/doctos_2016/ ensanut_mc_2016-310oct.pdf. Accessed 19 July 2018. 
14. Renehan AG, Tyson M, Egger M, Heller RF, Zwahlen M. Body-mass index and incidence of cancer: a systematic review and meta-analysis of prospective observational studies. Lancet. 2008;371:569-78.

15. Arnold M, Pandeya N, Byrnes G, Renehan AG, Stevens GA, Ezzati M, et al. Global burden of cancer attributable to high body-mass index in 2012: a population-based study. Lancet Oncol. 2015;16:36-46.

16. Cheraghi Z, Poorolajal J, Hashem T, Esmailnasab N, Doosti IA. Effect of body mass index on breast cancer during premenopausal and postmenopausal periods: a meta-analysis. PLoS One. 2012;7:e51446.

17. Feng $\mathrm{YH}$. The association between obesity and gynecological cancer. Gynecology and Minimally Invasive Therapy. 2015:4:102-5.

18. Picon-Ruiz M, Morata-Tarifa C, Valle-Goffin JJ, Friedman ER, Slingerland JM. Obesity and adverse breast cancer risk and outcome: Mechanistic insights and strategies for intervention. CA Cancer J Clin. 2017;67:378-97.

19. Kyrgiou M, Kalliala I, Markozannes G, Gunter MJ, Paraskevaidis E, Gabra H, et al. Adiposity and cancer at major anatomical sites: umbrella review of the literature. BMJ. 2017;356:j477.

20. Harvie M, Hooper L, Howell A. Central obesity and breast cancer risk: a systematic review. Obes Rev. 2003:4:157-73.

21. Palmer JR, Adams-Campbell LL, Boggs DA, Wise LA, Rosenberg L. A prospective study of body size and breast cancer in black women. Cancer Epidemiol Biomarkers Prev. 2007;16:1795-802.

22. Slattery ML, Sweeney C, Edwards S, Herrick J, Baumgartner K, Wolff R, et al. Body size, weight change, fat distribution and breast cancer risk in Hispanic and non-Hispanic white women. Breast Cancer Res Treat. 2007;102:85-101.

23. Van Den Brandt PA, Spiegelman D, Yaun S-S, Adami H-O, Beeson L, Folsom $A R$, et al. Pooled analysis of prospective cohort studies on height, weight, and breast cancer risk. Am J Epidemiol. 2000;152:514-27.

24. Berstad P, Coates RJ, Bernstein L, Folger SG, Malone KE, Marchbanks PA, et al. A case-control study of body mass index and breast cancer risk in white and African-American women. Cancer epidemiology, biomarkers \& prevention: a publication of the American Association for Cancer Research, cosponsored by the American Society of Preventive Oncology. 2010;19:1532-44.

25. Ng EH, Gao F, Ji CY, Ho GH, Soo KC. Risk factors for breast carcinoma in Singaporean Chinese women: the role of central obesity. Cancer. 1997;80:725-31.

26. Ogundiran TO, Huo D, Adenipekun A, Campbell O, Oyesegun R, Akang E, et al. Case-control study of body size and breast cancer risk in Nigerian women. Am J Epidemiol. 2010;172:682-90.

27. Harris H, Willett W, Terry K, Michels K. Body fat distribution and risk of premenopausal breast cancer in the Nurses' Health Study II. J Natl Cancer Inst. 2011;103:273-8.

28. La Vecchia C, Giordano SH, Hortobagyi GN, Chabner B. Overweight, obesity, diabetes, and risk of breast cancer: interlocking pieces of the puzzle. Oncologist. 2011;16:726-9.

29. World Cancer Research Fund/American Institute for Cancer Research: Continuous update project report: diet, nutrition, physical activity and breast cancer; 2017.

30. Chow LWC, Lui KL, Chan JCY, Chan TC, Ho PK, Lee WY, et al. Association between body mass index and risk of formation of breast cancer in Chinese women. Asian J Surg. 2005;28:179-84

31. Guo Y, Warren Andersen S, Shu XO, Michailidou K, Bolla MK, Wang Q, et al Genetically predicted body mass index and breast cancer risk: Mendelian randomization analyses of data from 145,000 women of European descent. PLoS Med. 2016;13:e1002105.

32. Amadou $A$, Hainaut $P$, Romieu I. Role of obesity in the risk of breast cancer: lessons from anthropometry. J Oncol. 2013;2013:906495.

33. Trayhurn P. Endocrine and signalling role of adipose tissue: new perspectives on fat. Acta Physiol Scand. 2005;184:285-93.

34. Ahima RS, Flier JS. Adipose tissue as an endocrine organ. Trends Endocrinol Metab. 2000;11:327-32

35. Shon HS, Jung ED, Kim SH, Lee JH. Free T4 is negatively correlated with body mass index in euthyroid women. Korean J Intern Med. 2008;23:53-7.

36. Knudsen N, Laurberg P, Rasmussen LB, Bulow I, Perrild H, Ovesen L, et al. Small differences in thyroid function may be important for body mass index and the occurrence of obesity in the population. J Clin Endocrinol Metab. 2005;90:4019-24.

37. Makepeace AE, Bremner AP, O'Leary P, Leedman PJ, Feddema $\mathrm{P}$, Michelangeli $V$, et al. Significant inverse relationship between serum free T4 concentration and body mass index in euthyroid subjects: differences between smokers and nonsmokers. Clin Endocrinol. 2008;69:648-52.
38. Guan B, Chen Y, Yang J, Yang W, Wang C. Effect of bariatric surgery on thyroid function in obese patients: a systematic review and meta-analysis. Obes Surg. 2017;27:3292-305.

39. Nam JS, Cho M, Park JS, Ahn CW, Cha BS, Lee EJ, et al. Triiodothyronine level predicts visceral obesity and atherosclerosis in euthyroid, overweight and obese subjects: T3 and visceral obesity. Obes Res Clin Pract. 2010;4: e247-342.

40. Montoya-Morales DS, de los Angeles Tapia-Gonzalez M, Alamilla-Lugo L, Sosa-Caballero A, Munoz-Solis A, Jimenez-Sanchez M. Alterations of the thyroid function in patients with morbid obesity. Rev Med Inst Mex Seguro Soc. 2015;53(Suppl 1):S18-22.

41. Kumar HK, Yadav RK, Prajapati J, Reddy CV, Raghunath M, Modi KD. Association between thyroid hormones, insulin resistance, and metabolic syndrome. Saudi Med J. 2009;30:907-11.

42. Angeles-Llerenas A, Ortega-Olvera C, Perez-Rodriguez E, Esparza-Cano JP, Lazcano-Ponce E, Romieu I, et al. Moderate physical activity and breast cancer risk: the effect of menopausal status. Cancer Causes Control. 2010:21:577-86.

43. Fejerman L, Romieu I, John EM, Lazcano-Ponce E, Huntsman S, Beckman KB, et al. European ancestry is positively associated with breast cancer risk in Mexican women. Cancer Epidemiol Biomark Prev. 2010;19:1074-82.

44. Fejerman L, John EM, Huntsman S, Beckman K, Choudhry S, Perez-Stable E, et al. Genetic ancestry and risk of breast cancer among U.S. Latinas. Cancer Res. 2008;68:9723-8.

45. Lohmann TG, Roche AF, Martorell R. Anthropometric standardization reference manual. Champaign: Human Kinetics Books; 1988.

46. Osuna-Ramírez I, Hernández-Prado B, Campuzano JC, Salmerón J. Indice de masa corporal y percepción de la imagen corporal en una población adulta mexicana: la precisión del autorreporte. Salud Publica Mex. 2006;48:94-103.

47. Nagin DS. Analyzing developmental trajectories: a semiparametric, groupbased approach. Psychol Methods. 1999:4:139-57.

48. Amadou A, Torres Mejia G, Fagherazzi G, Ortega C, Angeles-Llerenas A, Chajes $\mathrm{V}$, et al. Anthropometry, silhouette trajectory, and risk of breast cancer in Mexican women. Am J Prev Med. 2014;46:S52-64.

49. Hernandez-Avila M, Romieu I, Parra S, Hernandez-Avila J, Madrigal H, Willett W. Validity and reproducibility of a food frequency questionnaire to assess dietary intake of women living in Mexico City. Salud Publica Mex. 1998;40: 133-40.

50. Romieu I, Parra S, Hernandez JF, Madrigal H, Willett W, Hernandez M. Questionnaire assessment of antioxidants and retinol intakes in Mexican women. Arch Med Res. 1999;30:224-39.

51. Morales de León J, Bourges Rodríguez H, Camacho Parra M. Tables of composition of Mexican foods and food products (Condensed version 2015). Instituto Nacional de Ciencias Médicas y Nutrición Salvador Zubirán. 2016. http://www.innsz.mx/2017/Tablas/index.html\#page/1. Accessed 19 July 2018.

52. Food Composition Databases. United States Department of Agriculture, Maryland. 2008. https://www.ars.usda.gov/northeast-area/beltsville-md-bhnrc/ beltsville-human-nutrition-researchcenter/nutrient-data-laboratory/docs/usdanational-nutrient-database-for-standard-reference/. Accessed 19 July 2018.

53. Sallis JF, Haskell WL, Wood PD, Fortmann SP, Rogers T, Blair SN, et al. Physical activity assessment methodology in the Five-City project. Am J Epidemiol. 1985:121:91-106.

54. Martinez-González M, Sánchez-Villegas A, Faulin-Fajardo J. Bioestadistica Amigable. 2da ed. España: Diaz de Santos; 2006.

55. Hosmer D, Lemeshow S. Applied logistic regression. 2nd ed: John Wiley \& Sons; 2000

56. Willett W. Nutritional epidemiology. 2nd ed. New York: Oxford University Press; 1998

57. Qu HQ, Li Q, Lu Y, Fisher-Hoch SP, McCormick JB. Translational genomic medicine: common metabolic traits and ancestral components of Mexican Americans. J Med Genet. 2012:49:544-5.

58. Bruning PF, Bonfrer JM, Hart AA, van Noord PA, van der Hoeven H, Collette $\mathrm{HJ}$, et al. Body measurements, estrogen availability and the risk of human breast cancer: a case-control study. Int J Cancer. 1992;51:14-9.

59. Franceschi S, Favero A, La Vecchia C, Baron AE, Negri E, Dal Maso L, et al. Body size indices and breast cancer risk before and after menopause. Int J Cancer. 1996:67:181-6.

60. Harris RE, Namboodiri KK, Wynder EL. Breast cancer risk: effects of estrogen replacement therapy and body mass. J Natl Cancer Inst. 1992;84:1575-82.

61. Huang Z, Hankinson SE, Colditz GA, Stampfer MJ, Hunter DJ, Manson JE, et al. Dual effects of weight and weight gain on breast cancer risk. JAMA. 1997;278:1407-11. 
62. Kaaks R, Van Noord PA, Den Tonkelaar I, Peeters PH, Riboli E, Grobbee DE. Breast-cancer incidence in relation to height, weight and body-fat distribution in the Dutch "DOM" cohort. Int J Cancer. 1998;76:647-51.

63. Lahmann PH, Lissner L, Gullberg B, Olsson H, Berglund G. A prospective study of adiposity and postmenopausal breast cancer risk: the Malmo diet and cancer study. Int J Cancer. 2003;103:246-52.

64. Michels KB, Terry KL, Willett WC. Longitudinal study on the role of body size in premenopausal breast cancer. Arch Intern Med. 2006;166:2395-402.

65. Morimoto LM, White E, Chen Z, Chlebowski RT, Hays J, Kuller L, et al. Obesity, body size, and risk of postmenopausal breast cancer: the Women's Health Initiative (United States). Cancer Causes Control. 2002;13:741-51.

66. Sonnenschein E, Toniolo P, Terry MB, Bruning PF, Kato I, Koenig KL, et al. Body fat distribution and obesity in pre- and postmenopausal breast cancer. Int J Epidemiol. 1999;28:1026-31.

67. Tehard B, Lahmann PH, Riboli E, Clavel-Chapelon F. Anthropometry, breast cancer and menopausal status: use of repeated measurements over 10 years of follow-up-results of the French E3N women's cohort study. Int J Cancer. 2004;111:264-9.

68. Vatten LJ, Kvinnsland S. Prospective study of height, body mass index and risk of breast cancer. Acta Oncol. 1992;31:195-200.

69. Weiderpass E, Braaten T, Magnusson C, Kumle M, Vainio $H$, Lund $E$, et al. A prospective study of body size in different periods of life and risk of premenopausal breast cancer. Cancer Epidemiol Biomark Prev. 2004;13: 1121-7.

70. Friedenreich CM. Review of anthropometric factors and breast cancer risk. Eur J Cancer Prev. 2001;10:15-32.

71. Tehard B, Clavel-Chapelon F. Several anthropometric measurements and breast cancer risk: results of the E3N cohort study. Int J Obes. 2006;30:156-63.

72. Bouchardy C, Le MG, Hill C. Risk factors for breast cancer according to age at diagnosis in a French case-control study. J Clin Epidemiol. 1990;43:267-75.

73. Hu YH, Nagata C, Shimizu H, Kaneda N, Kashiki Y. Association of body mass index, physical activity, and reproductive histories with breast cancer: a case-control study in Gifu, Japan. Breast Cancer Res Treat. 1997:43:65-72.

74. London SJ, Colditz GA, Stampfer MJ, Willett WC, Rosner B, Speizer FE. Prospective study of relative weight, height, and risk of breast cancer. JAMA. 1989;262:2853-8.

75. Swanson CA, Brinton LA, Taylor PR, Licitra LM, Ziegler RG, Schairer C. Body size and breast cancer risk assessed in women participating in the breast cancer detection demonstration project. Am J Epidemiol. 1989;130:1133-41.

76. Tornberg SA, Holm LE, Carstensen JM. Breast cancer risk in relation to serum cholesterol, serum beta-lipoprotein, height, weight, and blood pressure. Acta Oncol. 1988;27:31-7.

77. Tretli S. Height and weight in relation to breast cancer morbidity and mortality. A prospective study of 570,000 women in Norway. Int J Cancer. 1989;44:23-30.

78. Vatten $L$, Kvinnsland S. Body mass index and risk of breast cancer. A prospective study of 23,826 Norwegian women. Int J Cancer. 1990;45:440-4.

79. Willett WC, Browne ML, Bain C, Lipnick RJ, Stampfer MJ, Rosner B, et al. Relative weight and risk of breast cancer among premenopausal women. Am J Epidemiol. 1985;122:731-40.

80. Huang J, Jin L, Ji G, Xing L, Xu C, Xiong X, et al. Implication from thyroid function decreasing during chemotherapy in breast cancer patients: chemosensitization role of triiodothyronine. BMC Cancer. 2013;13:334.

81. Yang XR, Chang-Claude J, Goode EL, Couch FJ, Nevanlinna H, Milne RL, et al. Associations of breast cancer risk factors with tumor subtypes: a pooled analysis from the Breast Cancer Association consortium studies. J Natl Cancer Inst. 2011;103:250-63.

82. Tang HY, Lin HY, Zhang S, Davis FB, Davis PJ. Thyroid hormone causes mitogen-activated protein kinase-dependent phosphorylation of the nuclear estrogen receptor. Endocrinology. 2004;145:3265-72.

83. Li H, Sun X, Miller E, Wang Q, Tao P, Liu L, et al. BMl, reproductive factors, and breast cancer molecular subtypes: a case-control study and metaanalysis. J Epidemiol. 2017;27:143-51.

84. Lin HY, Davis FB, Gordinier JK, Martino LJ, Davis PJ. Thyroid hormone induces activation of mitogen-activated protein kinase in cultured cells. Am J Phys. 1999:276:C1014-24.

85. Davis PJ, Shih A, Lin HY, Martino LJ, Davis FB. Thyroxine promotes association of mitogen-activated protein kinase and nuclear thyroid hormone receptor (TR) and causes serine phosphorylation of TR. J Biol Chem. 2000;275:38032-9.
86. Shih A, Lin HY, Davis FB, Davis PJ. Thyroid hormone promotes serine phosphorylation of p53 by mitogen-activated protein kinase. Biochemistry. 2001;40:2870-8.

87. Lin HY, Shih A, Davis FB, Davis PJ. Thyroid hormone promotes the phosphorylation of STAT3 and potentiates the action of epidermal growth factor in cultured cells. Biochem J. 1999;338(Pt 2):427-32.

88. Kawai M, Malone KE, Tang MT, Li Cl. Height, body mass index (BMI), BMI change, and the risk of estrogen receptor-positive, HER2-positive, and triplenegative breast cancer among women ages 20 to 44 years. Cancer. 2014; 120:1548-56.

89. Quigley DA, Tahiri A, Luders T, Riis MH, Balmain A, Borresen-Dale AL, et al. Age, estrogen, and immune response in breast adenocarcinoma and adjacent normal tissue. Oncoimmunology. 2017;6:e1356142.

90. Angelousi A, Diamanti-Kandarakis E, Zapanti E, Nonni A, Ktenas E, Mantzou A, et al. Is there an association between thyroid function abnormalities and breast cancer? Arch Endocrinol Metab. 2017;61:54-61.

91. Mendel CM, Weisiger RA, Jones AL, Cavalieri RR. Thyroid hormone-binding proteins in plasma facilitate uniform distribution of thyroxine within tissues: a perfused rat liver study. Endocrinology. 1987;120:1742-9.

92. Utiger RD. Estrogen, thyroxine binding in serum, and thyroxine therapy. N Engl J Med. 2001;344:1784-5.

93. Tosovic A, Bondeson AG, Bondeson L, Ericsson UB, Manjer J. T3 levels in relation to prognostic factors in breast cancer: a population-based prospective cohort study. BMC Cancer. 2014;14:536.

\section{Ready to submit your research? Choose BMC and benefit from:}

- fast, convenient online submission

- thorough peer review by experienced researchers in your field

- rapid publication on acceptance

- support for research data, including large and complex data types

- gold Open Access which fosters wider collaboration and increased citations

- maximum visibility for your research: over $100 \mathrm{M}$ website views per year

At BMC, research is always in progress.

Learn more biomedcentral.com/submissions 